\title{
Effect of Local Culture-Based Learning in Science on Critical Thinking and Student Communication Skills
}

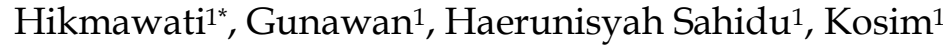 \\ ${ }^{1}$ Physics Education, University of Mataram, Mataram, Indonesia.
}

DOI: $\underline{10.29303 / \text { jossed.v2i1.713 }}$

\section{Article Info}

Received : February 28th 2021

Revised : April 15th 2021

Accepted: April 21 th, 2021

\begin{abstract}
Learning in every education unit in Indonesia is expected to develop good local cultural values so that it can make changes for the better in the future. In order to face future global competition, students at universities must have critical thinking and communication skills. This study aims to examine the effects of local culture-based learning in the field of Science on students' critical thinking and communication skills. The method used in this research is the quantitative method with a posttest-only control group design. The subjects in this study were 58 students who attended the Study and Learning lectures at one of the universities in Mataram. Learning theories discussed through local culturebased learning for 8 meetings are behavioristic, cognitive, constructivist, and humanistic learning theories. The instruments used in this study were a test of critical thinking skills and an assessment sheet for student communication skills. Data analysis to test the research hypothesis using SPSS 25. The research showed that there were differences in critical thinking and communication skills between groups of students whose learning was based on local culture in the field of Science and groups of students whose learning was using conventional models. The level of critical thinking skills and communication skills in the group of students whose learning is based on local culture in the field of Science is higher when compared to the group of students whose learning uses conventional models.
\end{abstract}

Keywords: local culture; critical thinking; communication.

Citation: Hikmawati, H., Gunawan, G., Sahidu, H., \& Kosim, K. (2021). Effect of Local Culture Based Learning in Science on Critical Thinking and Student Communication Skills. Journal of Science and Science Education, 2(1), 8-16. doi:https://doi.org/10.29303/jossed.v2i1.713

\section{Introduction}

Racial tensions that occur in an area can lead to strife and violence. Treatment in the form of culturebased learning has had a significant influence on students' attitudes towards multicultural relationships, and students also talk more and interact with other students who have different cultural backgrounds. Thus, culture-based learning will have a positive impact on students' social attitudes towards others when students have graduated from school and work (Baltes et al., 2015). The culture possessed by students affects messages about behavior, relationships, social units, or similar topics such as symbolic communication (Leonard et al., 2011). In other words, the influence of culture on student learning styles needs to be considered and cannot be underestimated (Raymond \& Choon, 2017).

Cultural locality as a product of local culture will characterize an area that is different from cultures in other regions, including in Indonesia, which has differences in race, religion, ethnicity, language, and customs. This uniqueness and diversity make its own color for the culture of the archipelago (Faizin, 2018). 
One example of a custom that is unique in one of the regions in Indonesia is the traditional marriage system of the Sasak tribe on the island of Lombok which is called Merarik (kawin lari). These customs have been influenced by elements in Islamic teachings and Balinese Hindu culture and Javanese culture. The procedure for implementing the Merarik custom which is a combination of cultural and religious elements can be witnessed by the presence of a marriage that is held by a Wetu Telu Muslim, the wedding is attended by customary stakeholders and will be led by a Kiyai santri (Hanapi, 2018).

Apart from the local culture "Merarik" on the island of Lombok, there is another local culture that has become a national event (annual activity), namely the Bau Nyale tradition. This tradition is still being carried out today because of the support of nature, the response of the community, and the government that provides opportunities through tourism (Purna, 2018). Bau Nyale is an activity of catching sea worms (nyale) carried out by the Sasak people on the island of Lombok who lives in the southern region. This tradition is now one of the tourism icons of West Nusa Tenggara province which is able to attract a lot of tourist interest, both local and foreign tourists during the rainy season. Nyale will appear around two to three nights, just before dawn. The Bau Nyale tradition can be seen in Figure 1.

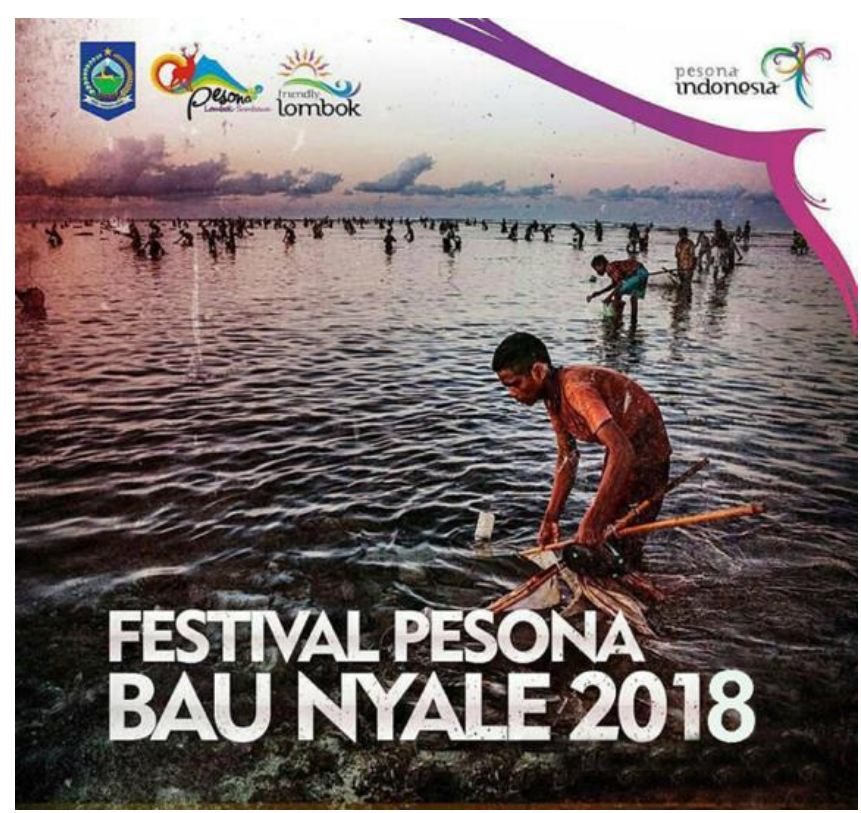

Figure 1. Bau Nyale. Source:

http://www.disbudpar.ntbprov.go.id/page/3/?s=nyale

The local culture that is part of a series of activities prior to the implementation of the Bau Nyale main event is cultural and performing arts performances, including "Peresean", which is a fight between two men with a rattan stick as a weapon (referred to as the "penjalin") and a shield derived from buffalo skin (referred to as "ende"). Peresean aims to preserve art and culture, it can be seen in Figure 2.

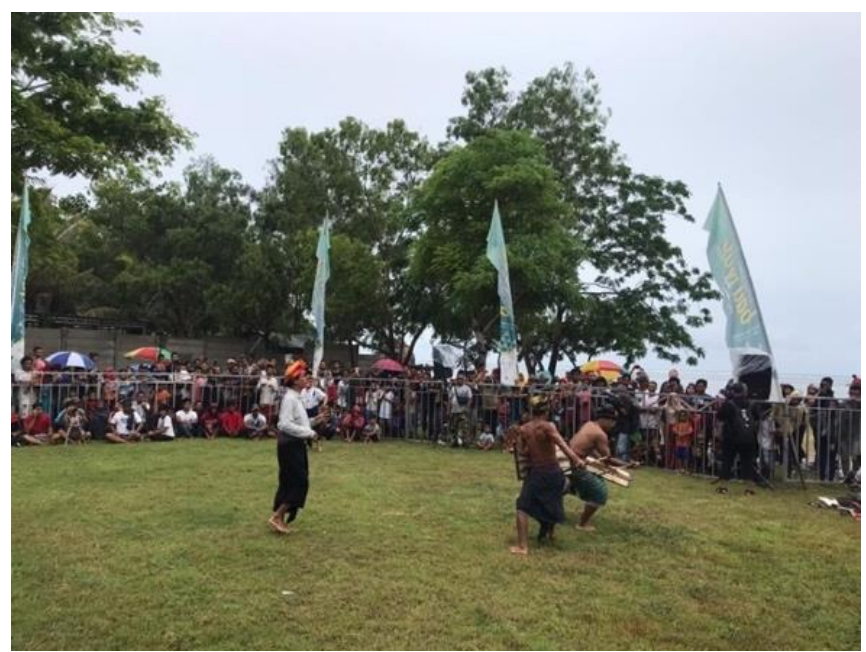

Figure 2. Peresean. Source:

http://www.disbudpar.ntbprov.go.id/?s=peresean

The Bau Nyale tradition can be used in local culture-based learning in the field of science in junior high schools. The local culture of the island of Lombok, apart from Bau Nyale, which has been identified as having an element of science (ethnoscience) is the traditional Sasak Sade village, the weaving process of the Sasak tribe, traditional musical instruments Gendang Beleq, and the process of making traditional Poteng Reket snacks (Hikmawati, et al., 2021a). Other local cultures that are still part of the traditions of the indigenous people in Lombok include awik-awik, mamak (mengirih), nyongkolan, and begawe (Hikmawati et al., 2021b).

Based on the explanation above, it can be said that education and culture are two related concepts. Cultured humans can be formed through education, and this culture will enable humans to live according to existing rules (Normina, 2017). RI Law No. 20 of 2003 explains that national education is education based on Pancasila and the 1945 Constitution of the Republic of Indonesia which is based on local religious and cultural values and cares for the demands of globalization.

Culture is an important aspect in planning educational curricula and culture is the driving force for the content of each curriculum. This is because the essence of education is to pass on cultural heritage to the younger generation. The educational goals of a nation can be achieved through the existing curriculum in each educational unit. The development of a country's human resources will be able to develop properly if the education system is strong. Cultural components must be integrated into curriculum 
planning so that the educational system products are as expected (Offorma, 2016).

The interaction of students with other students and the community and culture around them in learning will make an important contribution to individual development. This theory is referred to as culture-based learning which emerged from the ideas of psychologist Lev Vygotsky (Njok et al., 2014). Thus, due to this interaction, each student has its own characteristics so that the teacher must view students learning in a different way. Every student has interests and talents, as well as a variety of learning styles that are brought into the classroom learning situation. Besides that, students' culture, family background, the socio-economic level will also affect their learning. All of these components affect the chances of student success in learning (Mantiri, 2013). In other words, cultural values and local wisdom, as well as traditions that exist in the community, become the basis for students' habits in interacting with other people, how to think, and how to learn. These local values will experience a shift due to developments in information technology which will cause changes in the structure of life in society. Therefore, culture and local wisdom as part of social life should be used as a source and complement to learning so that students are easier and interested in finding solutions to problems related to the daily lives of students (Dazrullisa, 2018).

Cultural values, local wisdom, and traditions that exist in Indonesia are closely related to the character education strengthening program. Permendikbud RI No. 20/2018 explains that the program is implemented in an educational unit by implementing Pancasila values which include 5 things that are integrated into the curriculum, namely the value of religiosity, the value of nationalism, the value of independence, the value of mutual cooperation, and the value of integrity. Zubaidah (2019) argues that character education is an effort to provide 21st-century skills and to solve various negative cases committed by students. This character education must be supported by all parties, namely parents, families, teachers, communities, and the government. Suastra et al. (2017) revealed that students with good character have an important role in national development so that character development based on culture and local wisdom is needed.

According to Sabri (2015), the socio-cultural environment and cultural assumptions possessed by students have a significant effect on students' cognitive abilities, creativity, and critical thinking. In addition to these abilities, communication skills are also important to be developed along with the development of technology and information so that students have the skills needed according to the competencies needed in the 21st century today. Yokhebed (2019) suggests that communication skills are a person's ability to convey ideas or ideas clearly to others. The development of learning methods needs to be done as an effort to involve students in interacting and communicating their ideas or ideas to other students.

Septikasari \& Frasandy (2018) explain that students are required to have $4 \mathrm{C}$ skills, namely critical thinking and problem-solving, creative thinking, collaboration, and communication to face the challenges of the 21st century. Indonesia must be ready to face the development of science and technology so that it is not left behind from other nations.

Research-based on local culture in the field of science as an effort to develop students' critical thinking and communication skills is still rare. The purpose of this study was to examine the effects of local culture-based learning on science in Lombok Island on students' critical thinking and communication skills.

\section{Method}

Quantitative research methods have been used in this study and the research design chosen was a posttest-only control group (Azwar, 2007). The experimental group was given treatment in the form of local culture-based learning in the field of science, while the control group used conventional learning models (in the form of discussions).

The subjects of this study included 58 students who attended the Learning and Learning courses at one of the universities in Mataram. Learning theories discussed through local culture-based learning are behavioristic, cognitive, constructivist, and humanistic learning theories. Learning activities for 8 meetings took place online for both the experimental and control classes. Online lecture activities due to the pandemic are carried out based on the Presidential Decree No. 11 of 2020 on COVID-19.

The research instrument used was a test of students' critical thinking skills in the form of questions in the form of essays and assessment sheets for student communication skills in the form of observation sheets for online lecture activities. The hypothesis of this research is that students who follow local culture-based learning models in the field of science have better critical thinking and communication skills than students who follow conventional learning models. The process of analyzing research data to test hypotheses with MANOVA has used the SPSS 25 application package.

Multivariate analysis of variance (abbreviated as MANOVA) was used to test the mean difference in the effect of treatment on more than one dependent variable (Candiasa, 2020). In this study, the dependent 
variable is students' critical thinking and communication skills.

\section{Result and Discussion}

The results of the data normality test for students 'critical thinking and communication skills can be seen in table 1 . The values in the dependent variable of students' critical thinking skills in groups with local culture-based learning in the field of science and groups with conventional learning models respectively, namely 0.132 and 0.085 are greater than the values alpha 0.05 , therefore it can be said that the data is normally distributed. The value in the dependent variable of student communication skills in groups with local culture-based learning and groups with conventional learning models respectively, namely 0.200 and 0.173 , is greater than the alpha value of 0.05 , therefore it can be said that the data is normally distributed.

Table 1. Normality Test

\begin{tabular}{lllll}
\hline Variable & Group & Statistic & df & Sig. \\
\hline Critical & local culture & .148 & 27 & .132 \\
& conventional & .147 & 31 & .085 \\
Communication & local culture & .113 & 27 & .200 \\
& conventional & .133 & 31 & .173 \\
\hline
\end{tabular}

The results of the homogeneity test of the covariance variance matrix using the Box's $M$ test are shown in Table 2. The value for Box's M is 6,294 and the $\mathrm{F}$ value is 2,016 with a significance of 0.109 . The significance level of the study is 0.05 so that the Box's M value is not significant because of Sig. 0.109 is greater than the alpha value of 0.05 so that the null hypothesis is accepted, namely the covariance variant matrix of the dependent variable is the same for both groups. Therefore, the MANOVA analysis in this study can be continued.

Table 2. Box's M test results

\begin{tabular}{lll}
\hline No & \multicolumn{1}{c}{ Box's Test of Equality of Covariance Matrices } \\
\hline 1 & Box's M & 6.294 \\
2 & F & 2.016 \\
3 & df1 & 3 \\
4 & df2 & 1.589 .781 .900 \\
5 & Sig. & 0.109 \\
\hline
\end{tabular}

Because the 2 test hypothesis requirements have been met, the data analysis can be continued, namely using the MANOVA hypothesis test as follows. This study compares students' critical thinking and communication skills between a group of students who take local culture-based learning in the field of science and a group of students who take conventional learning. The decision taken was based on the analysis of Pillae Trace, Wilk Lambda, Hotelling Trace, Roy's Largest Root. The results of hypothesis testing with MANOVA can be seen in table 3.

Table 3. Results of hypothesis testing with MANOVA

\begin{tabular}{lllll}
\hline Effect & & Value & F & Sig. \\
\hline Group & Pillai's Trace & .387 & 17.332 & .000 \\
& $\begin{array}{l}\text { Wilks' } \\
\text { Lambda }\end{array}$ & .613 & 17.332 & .000 \\
& $\begin{array}{l}\text { Hotelling's } \\
\text { Trace }\end{array}$ & .630 & 17.332 & .000 \\
& $\begin{array}{l}\text { Roy's Largest } \\
\text { Root }\end{array}$ & .630 & 17.332 & .000 \\
\hline
\end{tabular}

Based on Table 3, information is obtained that the F value for Pillae Trace, Wilk Lambda, Hotelling Trace, Roy's Largest Root has the same value, namely 17.332 with a significance of 0.000 , much smaller than the alpha value of 0.05 (all $\mathrm{F}$ values are significant). Thus, there are differences in critical thinking and communication skills between students who take local culture-based learning and students who follow conventional models. Furthermore, to see which group is superior to other groups, the results of the descriptive test shown in Table 4 can be used.

Table 4. Descriptive Test Results

\begin{tabular}{lllll}
\hline & Group & Mean & $\begin{array}{l}\text { Std. } \\
\text { Deviation }\end{array}$ & $\mathrm{N}$ \\
\hline Critical & Local Culture & 79.07 & 9.639 & 27 \\
& Conventional & 70.74 & 7.019 & 31 \\
& Total & 74.62 & 9.268 & 58 \\
Communication & Local Culture & 79.59 & 8.087 & 27 \\
& Conventional & 69.97 & 5.648 & 31 \\
& Total & 74.45 & 8.371 & 58 \\
\hline
\end{tabular}

The descriptive test results showed that the local culture-based learning group had mean critical thinking and communication skills of 79.07 and 79.59, respectively. On the other hand, the conventional learning group had mean critical thinking and communication skills of 70.74 and 69.97, respectively. So, local culture-based learning groups in the field of science are better than groups with conventional learning, both for critical thinking and communication skills.

In this study, each dependent variable was also tested separately, so that the results of data analysis could be seen through the SPSS 25 output which displays the ANAVA test results per dependent variable. Before that, it must be seen the results of the variance homogeneity test using the Levene test as in Table 5. 
Table 5. Variance Homogeneity Test Results

\begin{tabular}{|c|c|c|c|}
\hline & & $\begin{array}{l}\text { Levene } \\
\text { Statistic }\end{array}$ & Sig. \\
\hline \multirow[t]{4}{*}{ Critical } & Based on Mean & 3.480 & .067 \\
\hline & Based on Median & 2.812 & .099 \\
\hline & $\begin{array}{l}\text { Based on Median and } \\
\text { with adjusted df }\end{array}$ & 2.812 & .100 \\
\hline & $\begin{array}{l}\text { Based on trimmed } \\
\text { mean }\end{array}$ & 3.472 & .068 \\
\hline \multirow[t]{4}{*}{ Communication } & Based on Mean & 3.991 & .051 \\
\hline & Based on Median & 3.470 & .068 \\
\hline & $\begin{array}{l}\text { Based on Median and } \\
\text { with adjusted df }\end{array}$ & 3.470 & .068 \\
\hline & $\begin{array}{l}\text { Based on trimmed } \\
\text { mean }\end{array}$ & 3.778 & .057 \\
\hline
\end{tabular}

All of the Levene test results in Table 5 show a significance value (sig.) Which is much greater than the alpha value of 0.05 . So, the variance of the two groups is homogeneous, so that the ANOVA test can be continued. Furthermore, it can be seen the different test results for each dependent variable separately in Table 6.

Table 6. ANOVA Results Per-Dependent Variable

\begin{tabular}{llll}
\hline Source & Dependent & F & Sig. \\
\hline Corrected Model & Criticale & 14.409 & .000 \\
& Communication & 28.171 & .000 \\
Intercept & Critical & 4.658 .324 & .000 \\
& Communication & 6.802 .167 & .000 \\
Group & Critical & 14.409 & .000 \\
& Communication & 28.171 & .000 \\
\hline
\end{tabular}

Table 6 shows that the difference in critical thinking skills between students who use culture-based learning in the field of science and students who use conventional learning results in an $\mathrm{F}$ value of 14.409 with a significance (Sig.) Of 0.000 . That is, there is a difference in the value of critical thinking skills due to different learning models. On the other hand, the difference in communication skills between students who take local culture-based learning in the field of science and students who take conventional learning results in an $\mathrm{F}$ value of 28,171 with a significance (Sig.) Of 0.000 , which also uses an alpha value of 0.05 . Thus, the learning model also results in differences in communication skills.

Learning theory discussed through local culturebased learning consists of 4 theories, namely behavioristic, cognitive, constructivist, and humanistic learning theories. Students are asked to analyze local culture in the form of local wisdom on the island of Lombok. Local wisdom can be viewed from various perspectives, namely history, customs, habits, indigenous and scientific knowledge that have to do with the application of the learning theory being studied. The application of learning theory in question is the application of every learning theory in learning activities, especially in science lessons at the junior high school level or in physics, chemistry, biology lessons at the high school level. Learning based on local culture in the field of science becomes more meaningful for students and at the same time can develop positive values found in the Indonesian culture.

Behavioristic learning theory views that stimulus (S) and response (R) are two causes of changes in student behavior. The interaction of $S$ and $R$ in the learning process in the classroom will result in changes in student behavior. Some experts in this theory argue about a person's behavior, namely as follows. Watson argues that genetic inheritance and environmental influences will cause changes in student behavior. Pavlov argues that in a set training procedure there is one $S$ and $R$ which will emerge again to replace the other $\mathrm{S}$ and $\mathrm{R}$ and thus develop a new R. Skinner argues that behavior change is caused by the relationship between $\mathrm{S}$ and $\mathrm{R}$ through student interactions with the environment. In other words, this learning theory focuses on developing student behavior to become better (Nahar, 2016).

Cognitive learning theory focuses on changes in internal mental processes experienced by students in understanding the external world, starting from learning simple tasks to complex tasks. Some cognitive learning theorists are as follows. Jean Piaget argues that students develop at the same stages even though the type and level of experience of each student is different. Lev Vygotsky argues that students' cognitive abilities are derived from social and cultural relationships. Lewin argues that student learning activities are a result of changes that occur in cognitive structures. Jerome Brunner expressed his opinion that knowledge is obtained by students independently through experience and experiments if it is supported by situations created in learning (Anidar, 2020).

Constructivism learning theory views that students can build their own knowledge with the help of others through the active involvement of a student in learning activities. A student produces knowledge and meaning based on experience (Sugrah, 2019). According to Utami (2016), Jean Piaget believes that students learn and construct their own knowledge (called constructivism theory), while Lev Vygotsky expressed his opinion that a student's cognitive development occurs as a result of the student's interaction with the social and cultural environment of the surrounding community (called sociocultural theory).

The last theory which is the topic of discussion in culture-based learning is the humanistic learning theory. This theory focuses on how to humanize 
students as human being and students can train their potential. The learning process according to this theory should begin and end with the students themselves. In other words, any theory may be used so that the goal of "humanizing humans" (to obtain self-actualization and so on) can be realized (Nast \& Yarni, 2019). Learning based on the humanist learning theory will present a conducive atmosphere and acknowledge the differences that each student has, and humanist education can create a more democratic and cooperative learning process (Sidik, 2016).

The application of the learning theories mentioned above (behavioristic, cognitive, constructivist, and humanistic) in culture-based learning in the field of science can be explained as follows. When students in junior high school learn about science, with the topic of classification of living things, the local culture raised is about the Bau Nyale tradition (catching sea worms). In preliminary activities, the teacher can ask students about the story of Princess Mandalika who turned into Nyale. One of the students can represent the class to tell about the legend of Bau Nyale. After that, the teacher can provide photos or videos about Bau Nyale. This can motivate students in learning and help students to focus on learning goals. Furthermore, the teacher can provide information about basic competencies and indicators of competency achievement.

In the core activity, the teacher can ask students to conduct investigations in groups to analyze the Bau Nyale tradition from various perspectives, such as the history of Puteri Mandalika and Bau Nyale, indigenous science (local wisdom of the Sasak tribe on the island of Lombok), and science. These investigative activities can be facilitated with the help of local culture-based Worksheets. After that students are asked to present the results of group work in the form of the relationship between Nyale (sea worms) and the topic of classification of living things. Students can provide a description of the characteristics of these sea worms. Sea worms (Nyale) are a type of sea worm which has the Latin name Eunice Viridis which is classified as a type of filumannelida. This sea worm belongs to the group (kingdom) Animalia. Worms (Vermes) are invertebrates. At this core stage, the teacher can open an open discussion to give students the opportunity to ask questions if there are still concepts that the student has not understood.

In the final activity, the teacher can ask students to make a conclusion to the concepts that have been learned. The teacher can also provide an evaluation both orally and in writing to determine the level of students' mastery of concepts. The accompanying impact that can be fostered from this culture-based learning is a caring attitude towards local culture which is one of the competencies of 21st-century students, including the attitude of preserving local culture, liking local culture, and introducing local culture to others.

Discussion activities through culture-based learning in the field of science (in the form of analysis of local wisdom in the form of traditions, habits, and local knowledge) in this study have been able to improve student's critical thinking and communication skills. The same thing was also found in Mitasari \& Prasetiyo's (2016) research, namely that the use of discussion and presentation methods are proven to improve the critical thinking and communication skills of a student. According to Angraini \& Wahyuni (2021), the characteristics of students who think critically are students who are able to find good solutions and solve problems appropriately.

The role of teachers/lecturers in local culturebased learning in the field of science includes giving students the opportunity to express their ideas that are rooted in local culture (Suastra, 2010). The teacher will succeed in improving students' critical thinking skills if the teacher remains focused and diligent from time to time (Udi \& Amit, 2011). Thus, education can be said to be a process of developing cultural values and civilization in society (Septiarti et al., 2017). Local culture including the local wisdom of an area can be preserved through formal education in schools and non-formal in the community (Dewi et al., 2020).

Local culture-based learning in the field of science can be done at every level of education, from early childhood to university. Local culture-based learning in the field of science is not only for students but also for teachers, for example through training activities or technical guidance. Solehuddin \& Budiman (2019) found that PAUD teachers in Indonesia need to have relevant understanding and experience related to the topics of social justice and multiculturalism so that they can teach students who come from multi-ethnic and religious communities. According to Alfulaila et al. (2019), this multicultural approach is suitable for use as a learning approach in Indonesia which has cultural diversity. The multicultural approach has been shown to be effective in improving writing achievement as part of students' communication skills. The same thing was expressed by Gusnawaty \& Nurwati (2019) that local culture-based learning can improve communicative competence. According to Sumarni \& Kadarwati (2020), learning based on local culture, especially those closely related to scientific concepts, including the field of science, needs to be emphasized. Learning based on local culture has been able to improve students' critical thinking and creative thinking skills.

The implementation of local culture-based learning can be viewed from 6 aspects, namely local 
culture-based program management, local culturebased learning materials, culture-based learning media, culture-based learning models, culture-based assessment, and evaluation of culture-based learning programs (Zuchdi \& Nurhadi, 2019). Local culturebased learning applied to educational units can not only be applied to develop critical thinking skills, communication, and character values for students and teachers, but also to develop competency standards for principals based on local wisdom values (Harsoyo et al., 2019).

Thus, local culture-based learning is closely related to character education, including students' caring attitudes towards the environment. According to Siswanto et al. (2019), learning that requires students to care about the environment can be integrated in all lessons. The competencies of students that are expected from the model of environmentally cultured education include the emergence of attitudes and behaviors with environmental cultures, the ability of students to understand cognitive about environmental culture education, as well as increased skills, creativity and productivity in students.

Character education in educational units can be carried out through learning activities in the classroom, habitual behavior that is enforced in schools, and extracurricular activities (Supriyadi et al., 2019). This character education is fundamental to the future of students. Therefore, local wisdom education that can teach positive values such as honesty needs to be applied starting from the family, school, and community environment (Gularso et al., 2019). The value of honesty as a student character developed through the 2013 curriculum can be integrated through the learning process in all lessons, so that dishonest actions that can be done by some students such as cheating while working on assignments or exams can be avoided (Sitorus et al., 2019).

\section{Conclusion}

Learning based on local culture in the field of science is a learning activity that can facilitate the preservation of local cultural values that exist and develop in the surrounding community by paying attention to the socio-cultural environment of students. Students in the group who took local culture-based learning in the field of science had better critical thinking and communication skills than students in the group who took conventional learning. Lecturers can ask students to analyze local wisdom from various perspectives, such as history, customs, habits, indigenous and scientific knowledge that have something to do with the application of the learning theory being studied so that learning becomes more meaningful and develops local cultural values owned by the nation. Indonesia. Learning based on local culture in the field of science can be an alternative learning model at universities as an effort to preserve local cultural values in Indonesia, improve critical thinking skills and improve student communication skills.

\section{References}

Alfulaila, N., Haryadi, Sudrajat, A., \& Nashrullah. (2019). The Effectiveness Of Multicultural Approach In Writing Achievement Of Indonesian Language Among Elementary School Students. Cakrawala Pendidikan, 38 (2), 366-376. doi: $10.21831 /$ cp.v38i2.23440

Angraini, L. M. \& Wahyuni, A. (2021). The Effect of Concept Attainment Model on Mathematical Critical Thinking Ability. International Journal of Instruction, $\quad 14 \quad$ (1), 727-742. https://doi.org/10.29333/iji.2021.14144a

Anidar, J. (2020). Teori Belajar Menurut Aliran Kognitif Serta Implikasinya Dalam Pembelajaran. UIN Imam Bonjol Padang. Retrieved 2020.

Azwar, S. (2007). Metode Penelitian. Yogyakarta: Pustaka Pelajar.

Baltes, B., Hernandez D., \& Collins C. (2015). Increasing Cultural Awareness Through a Cultural Awareness Program. Journal of Educational Research and Practice, 5 (1), 1-20. DOI: 10.5590/JERAP.2015.05.1.01

Candiasa, I. M. (2020). Analisis Data dengan Statistik Multivariat. Bali: UNDIKSHA Press.

Dazrullisa. (2018). Pengaruh Pembelajaran Matematika Berbasis Kearifan Lokal Terhadap Minat Belajar Siswa. Genta Mulia, 9 (2), 141-149.

Destri Sambara Sitorus*, Siswandari, Kristiani. (2019). The Effectiveness Of Accounting E-Module Integrated With Character Value To Improve Students' Learning Outcomes And Honesty. Cakrawala Pendidikan, 38 (1), 120-129. doi: 10.21831/cp.v38i1.20878

Dewi, I. S., Hastuti, U. S., Lestari, U., \& Suwono, H. 2020. Local Wisdom And Laboratory Experiment-Based Extension Booklet Development For Wadi Makers Of ElementaryEducated And Dropout Society In Central Kalimantan. Jurnal Pendidikan IPA Indonesia, 9 (4), 611-619. DOI: 10.15294/jpii.v9i4.23166

Faizin. (2018). Literasi Budaya Lokal Untuk Meminimalisir Gegar Budaya Pemelajar BIPA. Prosiding SENASBASA: Seminar Nasional Bahasa dan Sastra, 3, 116-124. http://researchreport.umm.ac.id/index.php/SENASBASA 
Gularso, D., Sugito, \& Zamroni. (2019). Kawruh Pamomong: Children Education Based On Local Wisdom In Yogyakarta. Cakrawala Pendidikan, 38 (2), 343-355. doi: 10.21831/cp.v38i2.21556

Gusnawaty, G. \& Nurwati A. (2019). A Learning Model Of Bahasa Indonesia As A Foreign Language Based On Local Intercultural Politeness. Cakrawala Pendidikan, Vol. 38, No. 1, 141-155. doi: 10.21831/cp.v38i1.23022Hanapi. (2018). Sistem Perkawinan Adat Ditinjau Dari Nilai- Nilai Pendidikan Islam Di Suku Sasak Lombok Nusa Tenggara Barat. EL-HIKAM: Jurnal Pendidikan dan Kajian Keislaman, 11 (1), 1-39.

Harsoyo, Y., C. Astuti, W. R., \& Rahayu, C. W. E. (2019). Competency And Values Of Local Wisdom Of High School Principals. Cakrawala $\begin{array}{llll}\text { Pendidikan, } 38 \text { (3), 565-577. } & \end{array}$ doi:10.21831/cp.v38i3.20593

Hikmawati, Suastra, I. W., \& Pujani, N. M. (2021a). Local Wisdom Analysis in Lombok Island with the Potential of Ethnoscience for the Development of Learning Models in Junior High School. The 10th International Conference on Theoretical and Applied Physics (ICTAP2020), Journal of Physics: Conference Series, $1816 \quad$ (012105), doi:10.1088/1742-6596/1816/1/012105.

Hikmawati, Suastra I. W., \& Pujani, N. M. (2021b). Ethnoscience-Based Science Learning Model to Develop Critical Thinking Ability and Local Cultural Concern for Junior High School Students in Lombok. Journal of Research in Science Education, 7 (1), 60-66.

Keputusan Presiden RI No. 11 Tahun 2020 tentang Penetapan Kedaruratan Kesehatan Masyarakat Corona Virus Disease 2019 (COVID- 19). [Presidential Decree No. 11 of 2020 concerning the Determination of the Corona Virus Disease 2019 (COVID-19) Public Health Emergency].

Leonard, K. M., Scotter, J. R. V., Pakdil, F., Chamseddine, N.J., Esatoglu, E., Gumus, M., Koyuncu, M., Wu, L. L., Mockaitis, A. I., Salciuviene, L., Oktem, M. K., Surkiene, G., \& Tsai, F. S. (2011). Examining media effectiveness across cultures and national borders: A review and multilevel framework. International Journal of Cross Cultural Management, 11(1), 83-103.

Mantiri, O. (2013). The Influence of Culture on Learning Styles. SSRN Electronic Journal, 1-17.

Mitasari, Z. \& Prasetiyo, N. A. (2016). Penerapan Metode Diskusi-Presentasi Dipadu Analisis Kritis Artikel melalui Lesson Study untuk Meningkatkan Pemahaman Konsep, Kemampuan Berpikir Kritis, dan Komunikasi. Jurnal BIOEDUKATIKA, 4 (1), 11-14.
Nahar, N. I. (2016). Penerapan Teori Belajar Behavioristik Dalam Proses Pembelajaran. Nusantara (Jurnal Ilmu Pengetahuan Sosial), 1, 6474.

Nast, T. P. J., \& Yarni, N. (2019). Teori Belajar Menurut Aliran Psikologi Humanistik Dan Implikasinya Dalam Pembelajaran. Jurnal Review Pendidikan dan Pengajaran, 2 (2), 270-275.

Njok, Cletus, P., \& Edinyang, S. D. (2014). SocioCultural Factors Affecting the Teaching and Learning of Social Studies in Nigeria. Journal of Education and Practice, 5 (24), 153-158.

Normina. (2017). Pendidikan Dalam Kebudayaan. Ittihad Jurnal Kopertais Wilayah XI Kalimantan, 15 (28), 17-28.

Offorma, G. C. (2016). Integrating components of culture in curriculum planning. International Journal of Curriculum and Instruction, 8 (1), 1-8.

Peraturan Menteri Pendidikan Dan Kebudayaan Republik Indonesia Nomor 20 Tahun 2018 Tentang Penguatan Pendidikan Karakter Pada Satuan Pendidikan Formal. [Regulation of the Minister of Education and Culture of the Republic of Indonesia Number 20 of 2018 concerning Strengthening Character Education in Formal Education Units].

Purna, I. M. (2018). Bau Nyale: The Valuable Tradition of Multiculturalism and Pluralism. Patanjala, 10 (1), 99 -114.

Raymond, C. Y. \& Choon, T. (2017). Understanding Asian Students Learning Styles, Cultural Influence and Learning Strategies. Journal of Education \& Social Policy, 7 (1), 194-210.

Sabri, P. S. U., Ilyas, M., \& Amjad, Z. (2015). Organizational Learning Culture and its Effects on Critical Thinking Skills on Female Teachers of Public Sector Higher Education Institutions. Bulletin of Education and Research, 37 (2), 69-90.

Septiarti, S. W., Hanum, F., Wahyono, S. B., Astuti, S. I. D., \& Efianingrum, A. (2017). Sosiologi Dan Antropologi Pendidikan. Yogyakarta: UNY Press.

Septikasari, R., \& Frasandy, R. N. (2018). Keterampilan 4C Abad 21 Dalam Pembelajaran Pendidikan Dasar. Jurnal Tarbiyah Al-Awlad, 8 (2), 112-122.

Sidik, F. (2016). Pendidikan Humanis Dan Implikasinya Dalam Pembelajaran. TADBIR Jurnal Manajemen Pendidikan Islam, 4 (1), 88-95.

Siswanto, Karimullah, Prasetyawati R., Nurhayati. (2019). Environmental Cultured Education And Its Implication On The Student's Competencies In An Adiwiyata School. Cakrawala Pendidikan, 38 (3), 552-564. doi:10.21831/cp.v38i3.23154

Solehuddin, M. \& Budiman, N. (2019). Multicultural Competence Of Prospective Preschool Teachers In Predominantly Muslim Country. Cakrawala 
$\begin{array}{llll}\text { Pendidikan, } & 38 & \text { (3), }\end{array}$

doi:10.21831/cp.v38i3.25033

Suastra, I. W. (2010). Model Pembelajaran Sains Berbasis Budaya Lokal Untuk Mengembangkan Kompetensi Dasar Sains Dan Nilai Kearifan Lokal Di SMP. Jurnal Pendidikan dan Pengajaran, 43 (2), 8-16.

Suastra, I.W., Jatmiko B., Ristiati N. P., \& Yasmini L. P. B. (2017). Developing Characters Based On Local Wisdom Of Bali In Teaching Physics In Senior High School. Jurnal Pendidikan IPA Indonesia, 6 (2), 306-312. DOI: 10.15294/jpii.v6i2.10681

Sugrah, N. (2019). Implementasi Teori Belajar Konstruktivisme Dalam Pembelajaran Sains. Humanika, Kajian Ilmiah Mata Kuliah Umum, 19 (2), 121-138.

Sumarni, W. \& Kadarwati, S. (2020). Ethno-Stem Project-Based Learning: Its Impact To Critical And Creative Thinking Skills. Jurnal Pendidikan IPA Indonesia, 9 (1), 11-21. DOI: 10.15294/jpii.v9i1.21754

Supriyadi, E., Zamtinah, Soenarto, S., Hatmojo, Y. I. (2019). A Character-Based Assessment Model For Vocational High Schools. Cakrawala Pendidikan, 38 (2), 269-282. doi: 10.21831/cp.v38i2.24099

Udi, E. A. \& Amit, M. (2011). Developing the skills of critical and creative thinking by probability teaching. Procedia Social and Behavioral Sciences, 15, 1087-1091.

Undang-Undang Republik Indonesia Nomor 20 Tahun 2003 Tentang Sistem Pendidikan Nasional. [Law of the Republic of Indonesia Number 20 of 2003 concerning the National Education System].

Utami, I. G.A. L. P. (2016). Teori Konstruktivisme Dan Teori Sosiokultural: Aplikasi Dalam Pengajaran bahasa Inggris. PRASI, 11 (1), 1-11.

Yokhebed. (2019). Profile of 21st Century Competency: Communication, Creativity, Collaboration, Critical Thinking at Prospective Biology Teachers. Bio-Pedagogi: Jurnal Pembelajaran Biologi, 8 (2), 94-97.

Zubaidah, S. (2019). Pendidikan Karakter Terintegrasi Keterampilan Abad Ke-21. Jurnal Penelitian dan Pengkajian Ilmu Pendidikan: e-Saintika, 3 (2), 1-24. https://doi.org/10.36312/e-saintika.v3i2.125

Zuchdi, D. \& Nurhadi. (2019). Culture Based Teaching And Learning For Indonesian As A Foreign Language In Yogyakarta. Cakrawala Pendidikan, 38 (3), 465-476. doi:10.21831/cp.v38i3.26297 